\title{
Local governments' binding regulations and their role in the framework of port activity
}

\author{
A. Dreiblathens \\ Rīga Stradiņš University, Riga, Latvia
}

\begin{abstract}
The importance and the great potential for improvements for Latvian ports are directly linked to its geographic position, being located between Europe and Asia. Due to the essential role it plays in maritime, Latvian ports cannot be excluded from the international law of the Sea. A prerequisite for maritime safety insurance in ports is the development of maritime security and port legal acts in accordance with the modern international law and regulations. Operations of the major ports in Latvia as well as the maritime safety in ports are controlled and regulated by binding rules issued by municipalities. This study focuses on examining the norms included in the port regulations as well as to what extent ports are capable of ensuring navigation safety in ports according to the legal framework. The study also compares and analyzes the differences in legal frameworks in the major Latvian ports, their solution in improving the regulations and suggests a possible way how the port rulemaking body should be structured.
\end{abstract}

\section{Introduction}

Latvia is also known as a sea state with more than $500 \mathrm{~km}$ long sea border, ten ports along the coast and intensive shipping activity. Increase in cargo turnover at ports and, hence, the density of traffic, increases the need to ensure safe navigation and marine environment as well as coastal protection. Achieving these objectives depends on the International Maritime Organization Convention of effective implementation and subsequent application. It is therefore important to implement international instruments on maritime affairs, that is, international agreements and standards of maritime safety, pollution prevention and efficiency of maritime security fields. Internationally the requirements are eligible to ship, ship's personnel, cargo, navigation, and safety of people in the sea, as well as safety in ports.

Maritime security problem is one of the most important issues in maritime, as it determines the ship's crew and passenger safety and life, marine cargo and marine environment preservation. Shipping has always been inextricably linked to the security of legal security due to its importance of studying and evaluating the movements of ships safety regulatory characteristics, which are included in the port rules. Port importance and great potential for its development are related to Latvia's geographical location between Europe and Asia. Latvia can be considered as a border country between the European and Asian markets, allowing the development of Latvian ports based on two huge market services.

Latvian ports are operated within the framework of special territory regimes, where a special controlling law is applied, which differs from the general national legislation. Creation of the special controlling law was a significant step in the history of Latvian economy. At early stages of creation of the special law the outcome was unpredictable, however as the time has passed it can be concluded that the creation of a special area has been efficient and highly important for Latvian ports. Creating the Freeport of Riga and Ventspils port MASTER 
were exposed to these Freeport administrations, but the creation of Liepaja Special Economic Zones - Liepaja Special Economic Zone Authority.

The objective is to analyze the legislation in Latvian Republic which regulates maritime safety and control services in the territory of Latvian Republic and maritime ports, and on the basis of the inspection services performed maritime regulations control. Another objective is to explore these nuances in order to identify the critical points of the port legislation whose legal framework should be in accordance with international maritime law and, at the same time not being bothersome, but helpful for vessels entering Latvian ports. This study will be both scientifically and practically very significant.

Work assesses Latvian legislation (maritime) as well as the rule of the largest Latvian ports in accordance with the international law. It identifies solutions for their development and expresses the author's vision whether port rulemaking body should be developed.

\section{The Legislation of Latvian ports}

Riga, Liepaja and Ventspils Harbourmasters office is run by harbour masters, whose fundamental duty is to ensure the safety of navigation in Latvian ports and roads to ports. MASTERS are also part of the port control service, the vessel traffic officers, pilots and other employees.

Competence of Maritime Administration is laid down in the Maritime Administration and Marine Safety Law Article 6 [3] in accordance with the laws and norms of international law and its tasks are:

- To monitor the vessels included in the register of ships with the safety requirements, approve the shipbuilding and modernization of technical projects and issue ships' certificates;

- To be the subject of ship register Tonnage Measurement of Ships, and supporting documents issued by the tonnage;

- To approve the ship documentation;

- To implement national control in the port for foreign vessels;

- To control by the International Safety Management Code (hereinafter - ISM Code) requirements in relation to foreign ships;

- To carry out the assessment of professional competence of seafarers in the event of a breach of professional duties related to the improper performance or non-performance;

- To control how the waters of the Latvian Republic comply with the procedure for reporting the passengers on board, as well as the dangerous and polluting goods;

- To harmonize the rules for port maritime safety and control of compliance;

- To issue certificates to pilots and ship traffic (VTS) operators, as well as take on training of pilots and vessel traffic management (VTS) operators and monitor examinations;

- To draw up, issue, change, hold, cancel, declared unfit for seaman's books and perform the tracking processing of personal data in connection with a seaman and professional qualification certificates for ships, as well as maintain certification of seafarers' database;

- To evaluate and coordinate seafarers' vocational education programs and training in compliance with the international law, organized by the seafarers' inspection and issue professional qualification for ships;

- To register ship and ship mortgage and issue related documents;

- To maintain the register of ships and fishing vessels registry database;

- To monitor the beacons, buoys, and other aids to navigation system for the establishment and operation in the Republic of Latvia waters; 
- To control the depth measurements, as well as hydrographical measurements and research in Latvian waters;

- To organize preparation, printing and distribution of nautical publications;

- To coordinate retrieval of sunken property from waters of the Latvian Republic from the point of view of maritime safety;

- To coordinate the port hydraulic structures and waterway projects from the viewpoint of maritime safety and participate in project recruitment;

- To participate in the International Maritime Organization, the Helsinki Commission, the International Hydrographical Organization and other international organizations;

- To prepare proposals for the development of draft laws and regulations; certified by recognized security conventions;

- Supervised by a recognized security organization, as well as the activities of classification societies;

- To carry out the functions of the organizations responsible for the implementation of the ISPS Code requirements and control;

- To coordinate training programs of the ships, shipping companies, ports and port facility security personnel with the ISPS Code;

- For ensuring that merchants who assemble the crew and arrange personal work on ships to meet the requirements set out in the 1978 International Convention on Standards of Training, Certification and Watchkeeping, and Watchkeeping for Seafarers, as amended requirements;

- To issue certificates to seafarers training instructors and professional qualifications of seafarers evaluators attesting to their compliance with the 1978 International Convention on Standards of Training, Certification and Watchkeeping, and Watchkeeping for Seafarers, as amended requirements;

- To issue a certificate of compliance (certificate) to a merchant engaged in shipbuilding, design, modernization or repair;

- To issue a certificate of compliance (certificate) to enterprises engaged in the ship's safety equipment inspections;

- as well as to develop its tariffs for paid services related to hydrography, maritime security, environmental pollution prevention, preparation and certification of seafarers.

This feature of Latvian Maritime Administration provides Mariners Register of Shipping, the Maritime Safety Inspectorate and the Ship and Port Security Division, as well as the Hydrographic Service operation.

\section{Local government binding regulations - Port Regulations}

Shipping in the port of Riga governed by 7 March 2006, the Riga City Council Binding Regulations No. 42 "Freeport of Riga Regulations" issued on the basis of the Law on Ports of Article 6 of the first instalment. Freeport of Riga Authority shall determine the internal procedures of the Freeport of Riga and safety of navigation in Riga Free Port. The rules are laid down in the Freeport border arrangements for the provision of information on ships entering and leaving port. Necessary documents, communication system, port pilots and vessel traffic services, ship motion procedures and limits for ships in port and mooring regulations berths preparation and conditions of use, un-berth order, protection of the environment, dredging procedures for port safety and security principles, customs, border guards, bathroom and fire mode, port fees to be charged and liability for violation of port regulations. There are certain powers of the Harbour Master, detention order, hydraulic structures and equipment operating rules, tug services and the rules and fishing regulations 
in the port basin. In addition, it states that without these rules of the Republic of Latvia and international laws and regulations, ships, merchants, individuals and legal entities located or operating in the port are as followed:

- IMO Recommendations for safe transport of dangerous goods and related activities in ports (IMO Recommendations on the Safe Transport of Dangerous Cargoes and Related Activities in Port Areas, IMO Circular MSC/Circ.675);

- IMO Cargo Safe Stowage and Securing Code with its amendments (IMO Code of Safe Practice for Cargo stowage and Securing, IMO Resolution A.714 (17));

- 1997, "Ro-ro terminal safe operation" (ICHCA Safe Operation of Ro-Ro Terminals, 1997);

- IMO Bulk Carriers Safe Loading and Unloading Code of Practice (BLU Code, Code of Practice for the Safe Loading and Unloading of Bulk Carriers (BLU Code), IMO Resolution A.862 (20));

- IMO, the International Labour Organization, the UN European Economic Committee issued Guidelines for packing of cargo transport units (IMO/ILO/UN ECE Guidelines for Packing of Cargo Transport Units (CTUs), 1997);

- International Association of Ports guide "Dangerous goods and port environment" (IAPH Dangerous Goods and Port Environment);

- International Oil Tanker and Terminal Safety Manual (ICS/OCIMF/IAPH International Safety Guide for Oil Tankers \& Terminals - ISGOTT);

- International grain in bulk, the safe transport of the Code (International Code for the Safe Carriage of Grain in Bulk, IMO Resolution MSC.23 (59));

- IMO Code of Safe Practice for Ships Carrying Timber board and its amendments (Code of Safe Practice for Ships Carrying Timber Deck Cargoes, as amended, IMO Resolution A.715 (17));

- 1998 "Safe operation of container ships" (ICHCA Safe Working on Container Ships, 1998);

- The International Ship and Port Facility Security Code (International Ship and Port Facility (ISPS) Code) [2].

For non-compliance the person shall be held to administrative, civil or criminal liability. Person's prosecution of administrative, civil or criminal liability does not remove the obligation to compensation in civil law. Freeport of Riga Authority shall not be liable for any other legal or natural person's act or omission results and is entitled to any damages caused to the port a full refund.

From May 1, 2011, work was commenced by Freeport of Riga Authority Port Police. The port police regulations provide - within its competence to monitor compliance with port regulations; to ensure that persons, vehicles and cargo movement are checked in the port and port area crossing the land border; to control protection against pollution in the port area; to control compliance with the International Ship and Port Facility Security Code (ISPS) requirements in the port; to control port organizations located in operation according to the port facility security plans; to ensure land border controls in the port area; within its competence to provide port inland water/water area/control; provide individual and public safety. In addition, according to the Cabinet of Ministers 1060 "Regulations on Hazardous and Polluting Cargo Handling and Control in Ports" Port Police duties include conducting checking of dangerous and polluting cargo terminals; eliminate administrative and other offenses; detect administrative violations; normative acts in order to provide assistance to individuals, businesses and organizations in the protection of the rights and in accordance with statutory duties in the port area; in accordance with its competence to apply administrative sanctions. 
The port police structure includes: Ports police management; Administrative Office; Operational Management Division; Public Order Control Division; Port perimeter security department; the port's internal security service. The port police carry out their duties in close cooperation with the State Police and Security Police, including guaranteeing the NATO civilian and other cargo security at the port of Riga.

Shipping in the port of Ventspils 21 November 2005, governing the binding rules No. 5 "Ventspils Free Port Rules", issued in accordance with the Law on ports in Article 6. These rules define the boundaries of the Freeport of vessels permitted dimensions and parametric navigable port basin, the establishment of vessel traffic service and coastal radar stations operating procedures for pilots and tug services exercise routines, exercise routine berth, ship traffic restrictions and prohibitions, mooring operations procedures and cargo Passenger Operations Procedures, detention, arrest, formalities and reporting arrangements. It sets Immigration, Customs, badges and bathroom regime, environmental regulations and prohibitions, fire regime. Certain dredging arrangements, structures and equipment protection, port fees, harbour master regulated activity, communication structure and responsibilities of the Freeport of non-compliance.

Freeport Authority, the natural or legal person who operates the Freeport, is not responsible for any other legal or natural person's act or omission results and has the right to seek redress for any losses incurred under civil law, the law "Maritime Code" and other applicable laws and regulations.

Additional conditions this provision requires are, that all vessels and companies (corporations), organizations, legal and natural persons located or operating in Freeport, without these provisions have Latvian Republic and international regulatory enactments:

- The International Maritime Organization recommendations for the safe transport of dangerous goods and related activities in ports (IMO Recommendations on the Safe Transport of Dangerous Cargoes and Related Activities in Port Areas (IMO - 290E, 1995));

- The International Maritime Organization Cargo Stowage and Securing Safe Code (IMO Code of Safe Practice for Cargo stowage and Securing (IMO - 292E, 1992)) and the 1994/1995 Code of Corrections (1994/1995 Amendments to the Code IMO - 295E, 1995);

- Ro-ro terminal Safe Operation In 1997. (ICHCA Safe Operation of Ro-Ro Terminals, 1997);

- Safe operation of container ships, 1998. (ICHCA Safe Working on Container Ships, 1998);

- Solid bulk cargo loading and unloading, 1998. (ICHCA The Loading and Unloading of Solid Bulk Cargoes, 1998);

- IMO/ILO/UNECE Committee Guidelines for packing of cargo transport units (IMO/ILO/UN ECE Guidelines for Packing of Cargo Transport Units (CTUs) (IMO - 284E, 1997));

- International Association of Ports and Port Dangerous goods Environment (IAPH Dangerous Goods and Port Environment);

- The International Ship and Port Facility Security Code (ISPS Code - International Code for the security of ships and of port facilities - ISPS code);

- International Tanker and Terminal Security Guide - ISGOTT (International Safety Guide for Oil Tankers and Terminals) [2].

Shipping in the port of Liepaja governed by December 20, 2007 Liepaja City Council Regulation No. 23 "port regulations". These rules set out the boundaries of the port, communications port, the port captain's powers berths Terms pilotage and tug services 
arrangement anchorage limits and procedures for the use of their ships entry and shipping arrangements for the port basin, the technical capabilities of ships, ships in port and leaving the port, Terms, diving on the agenda, the port dredging and small vessel traffic arrangements. There are certain fire safety, environmental protection, bunkering, ship, port and port facility security rules. Set of customs, border guards and sanitary arrangements, port fees and liability for non-compliance of the port. The port is responsible for the rules of any natural or legal person under the Administrative Offences Act and other applicable laws and regulations. Any indication or reference to international laws and regulations, in addition to those provisions for ships and companies (corporations), organizations, individuals and legal persons located or operating in the port area is not marked.

Liepaja Special Economic Zone will be established by 2036, Ventspils Freeport by 2017, but Riga Freeport by 2020 with the aim of developing and promoting trade, industry, shipping and air traffic, as well as the international exchange of goods through Latvia. In other words, they are set up to develop in the individual regions, as well as in the country as a whole, the economic situation, as well as attract investments both from abroad and from Latvia. They have established strategic territorial places - at the borders, water, air routes and railways. In order to attract businesses, potential partners and investors, these zones have created a special tax regime that provides for specific tax incentives. However, not all businesses are fully aware of the situation. In this case, the tax relief acquisition means not only an attractive business environment, but is faced with additional costs of maritime security in ports. Not infrequently, for entrepreneurs, however, it is not a priority and maritime safety remains the second plan role.

\section{Specifics of Port Regulations in EU major ports}

Rotterdam is one of Europe's largest ports, its port rules are included in the following sections: transport of dangerous goods regulations on inland waterways, marine waste transfer procedures for handling hazardous substances regulations, requirements for ships linesmen organizations and boatmen, preparation of ship cargo operations, there is a definite port captain's competence and responsibility. There are procedures in ships' cargo operational limitations of the vessel traffic sign placement procedure, marine engines use restrictions if they are located at the berths, anchor or aground, anchoring restrictions, reporting arrangements, ports and environmental safety regulations, bunkering and fuel handling area with certain open fire and smoking restrictions. There are certain zoning regulations in respect of vessels carrying dangerous substances in packaged form or in containers. Provision is included in a separate section of the port services - mooring and unmooring procedure linesmen competence and certification requirements, safety requirements for ships linesmen and passengers and port security rules [4].

These rules do not contain port shipping restrictions for meteorological reasons but unlike the great Latvian port rules focus on navigation signs placement rules and ship linesmen competence, certification and security, as one of the largest ports in the EU, port of Amsterdam should be mentioned. Its port rules contain a section of the general definitions and scope, the general rules for permits, exemptions and guidelines, terms of use and management of ports, navigation marks, locks and bridges of use, an indication that the municipal officials may issue additional rules with respect to the minimum speed of the shipping port. Moreover, public order is included in the environmental and safety regulations. Provided that ship or boat mooring linesmen company shall not engage in ship berthing municipal officials without permission and mooring Terms tankers liability for non-compliance and transitional and final provisions [6]. 
Also these rules, similar to the Rotterdam port rules, do not set limits for hydrometeorological reasons, but include a disclaimer that they might be issued. Attention is also drawn to the ship linesmen competence and certification. These port regulations are not focused on the reservation restrictions (speed, wind, visibility), but cover the responsibility for the accident causing the ship's safe speed while leaving the choice of selection for ship's captain.

In addition, wind and visibility criteria for the restriction are objectively impossible to develop and it is possible only after examining the length of the ship or tonnage. Each individual board equipment and ability to manoeuvre is very individual, so it is not reflected in the regulations.

Kaliningrad port rules also contain provisions requiring ships maximum speed limits. They are 6 to 9 knots according to precipitation vessel. Wind strength limits are set by the shipping lengths. The rules also included a provision that the movement of vessels is only allowed after permission from the VTS [7]. Similarly, large ship rules of Latvian ports fail to address linesmen certification and competence.

Therefore it is concluded that the Port Authority of Latvian ports is substantially different from other European ports. These included provisions which by their nature are directly threatened by the restriction of vessel traffic participants in civil protection. Despite the fact that in the world there are not the same two ports, each port and port rules are tailored to the specific port, however, the responsible authorities and Latvian, particularly local authorities, should be avoided in such a provision included in its binding provisions. It is not acceptable that binding rules may be the risk of port workers' rights; direct the work to be conscientious fulfilment.

\section{Typical problems of Maritime Safety in Latvian large ports}

VTSC currently operates a modern navigation and communication equipment complexes that are capable of ensuring the vessel traffic safety conforming to global standards. This facilitates safe entry of vessels into Latvian ports and speeds up the Latvian incorporation into the Global Maritime Distress and Safety System (GMDSS) and early warning systems (Early Warning System), which is of utter importance for carriers of dangerous goods in the Baltic Sea. VTSC are located in the port control services, harbour masters and shipping operators. VTSC employees vessel movement data are used to process a/s HMS design of information systems Tug - one of the most advanced IR ports of the Baltic countries. In addition, the Latvian Maritime Administration Service Hydrographic Surveying part of Latvian is the only institution that prepares and publishes nautical charts both electronic and paper format. Maritime Administration prepared maps covering all territorial waters and exclusive economic zones of the Republic of Latvia. Cartographers' performance depends on the number of high-quality, accurate, understandable and convenient to use map received by sailors not only in Latvia, but almost all over the world.

However, studying the port operations, port interviews with senior management, maritime safety and analysis of questionnaires filled out by port workers who are directly related to safety of navigation, it is clear that there are substantial problems of maritime safety legislative framework:

1) Port Regulations are included in the rules, such as the maximum sailing speed of 8 knots as defined in rule 71 of the Freeport of Riga, Ventspils Free Port 5 knots provisions of Paragraph 67 and Liepaja port specified in Paragraph 70, observance of such rules is often not possible because it depends on the technical characteristics 
of the vessel, the weather, currents, shipping lines and a number of other conditions. Often there are cases when in accordance with good seagoing ship safe speed exceeds the limitations of the ship's captain, the pilot and the vessel traffic service operators in compliance with the provisions of the port is not possible. Failure to comply with such a port (port rules are issued by local government administrative act) provides both administrative (Appendix 2) and the civil as well as criminal liability.

2) One-way traffic in the port basin is defined by rule 71 of the Freeport of Riga, Ventspils Free Port and the provisions of Paragraph 69 of the provisions of Paragraph 81 of the port of Liepaja. In Liepaja such a movement limits the rule, vessel traffic service operators have to infringe on a daily basis. These buoys located 2.5 nautical miles from the port gates and two-way movement of vessels, after considering the circumstances, is practically impossible, at least another 1-1.5 nautical miles. Without doubt, no legislative act violates these rules but given that the MASTER is subject to Freeport Authority, or in the case of Liepaja - LSEZ administration, which by their nature have a commercial interest in the ship and increasing the turnover of such employee behavior can be seen as an obstacle to business, and may be revised in the issue of employee competence or compliance Positions post, despite the fact that the rules have a disclaimer that the decision may be taken by the VTS operator. As a result, the potential consequences are again civil - dismissal of an employee.

3) As one of the biggest problems in port operations structure is the form of subordination MASTER Freeport administrations and Liepaja - Liepaja Special Economic Zone Authority, which is essentially a commercial. MASTER is directly responsible for ensuring the safety of maritime ports and its exposure to commercial entities is not only illogical, but also dangerous to the safety of navigation, causing environmental pollution threat and danger to human life at sea.

4) In accordance with IALA [8] VTS liability is limited or restricted areas and form, as an advisory and support delivery operations in these areas. This means that the VTS is the provision of information and services for all KSD recommendations can only serve as recommendations. However, in all major Latvian port rules are included in the items that ship movements may be commenced only after receiving authorization from the KSD. Consequently, the VTS operators are obliged to act contrary to international standards - or not to permit the vessel to initiate movement. This harbour provisions, of course, cannot produce legal effects of the VTS operator, but the ship owners or captains have the right to defy the orders of the VTS operator according to the norms of international law and typing Marine protest KSD such behaviour can lead to legal consequences Latvian state.

5) The Latvian legislation has not stipulated ships linesmen certification, so that ships can moor and unmoor person without special training. This in turn poses a threat to human safety of ships mooring procedures. Latvian large ports ships linesmen competence is confirmed if the person has a rating holding a certificate, and totally sufficient for the certificate of conformity - Sailor inland waterway vessels. But Able Seamen working on ships differ significantly from the ship boatmen's work. There are other specifics. Inland water vessels are generally small, but the ship linesmen mostly work with largesize vessels. Mooring is neither trained nor secure.

6) No large port rules stipulate the maximum vessel length of the port that in linesmen service is obligatory. Consequently, the vessels are able to put them to use and cables ship with his crew's help. This poses a direct threat to maritime and human security. In this case, a breach of the SOLAS Convention, as the crew members berthing their vessels are delivered to the quay without Convention shall, at the appropriate equipment. 
7) Port Regulations do not specify a minimum distance of buoy placement on the fairway. The vessel walking down the fairway main landmark is the direction of a guide or buoys. Unless otherwise specified, the minimum visibility which allows the movement of vessels is $0.3 \mathrm{~nm}$. The buoys should be from each other no further than $0.3 \mathrm{~nm}$ Poor visibility is when the lights are not visible to the guidelines, such buoys may protect the port from ship swerve off course and stranding, which in turn can lead to ports pilots and ship captains civil effects. However, the following safety regulations in Latvian large port rules are not included.

\section{References}

[1] http://www.imo.org/Conventions/contents.asp?doc_id=651\&topic_id= 257. Observed 23.04.2014.

[2] The International Ship and Port Facility Security Code (ISPS Code, the English translation by the non-profit-making organization, State stock company Maritime Administration of Latvia, 2004.

[3] The law, "The Maritime Administration and Marine Safety Law" http://likumi. lv/doc $\cdot$ php?id=68491. Observed 10.12.2014.

[4] Cabinet of Ministers rules Nr. 895 "Mariner certification rules", http://likumi. lv/doc.php?id=123870. Observed 10.12.2014.

[5] Cabinet of Ministers rules Nr. 748 "The rules for ship and shipping company, port and port facility security and monitoring the performance of the functions of the", http://likumi.lv/doc.php?id=166672. Observed 10.12.2014.

[6] http://www.portofamsterdam.nl/docs/uk/Legislation $\% 20$ and $\% 20$ regulations/Regionale $\% 20$ havenverordening $\% 20$ NZK $\% 202010 \% 20$ engelstalige\%20versie $\% 20$ def $\% 20100426$. pdf . Observed 10.12.2014.

[7] http://www.intorg.gazinter.net/english/regulation_2_eng.htm. Observed 10.12.2014.

[8] http://www.iala-aism.org/iala/publications/documentspdf/doc_262_ eng.pdf . Observed 10.12.2014. 